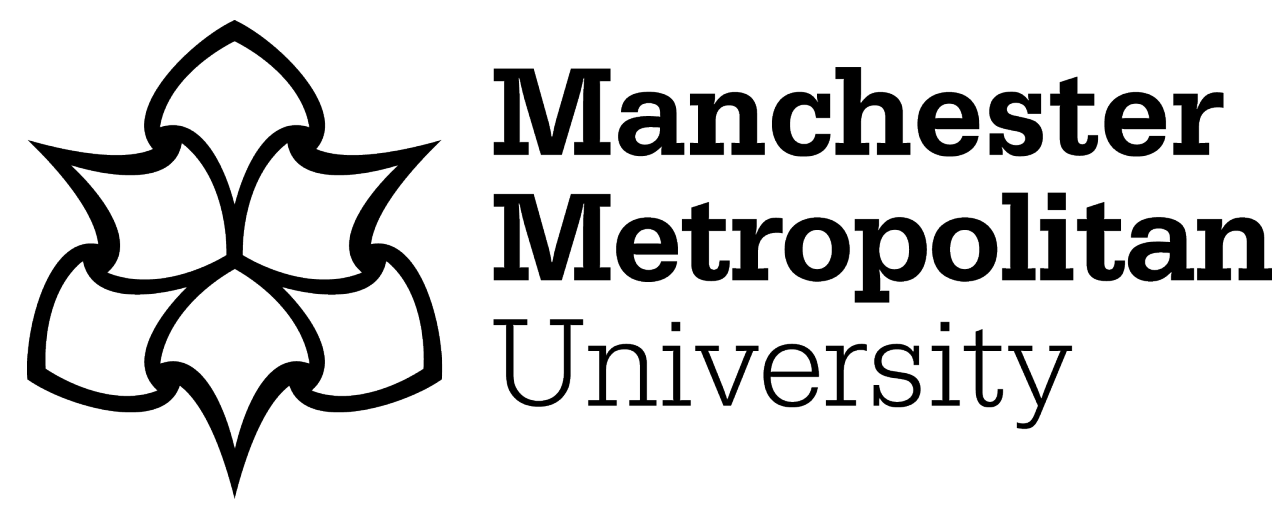

Hampton, MP, Jeyacheya, Julia and Lee, Donna (2017) The political economy of dive tourism: precarity at the periphery. Tourism Geographies, 20 (1). pp. 107-126. ISSN 1461-6688

Downloaded from: https://e-space.mmu.ac.uk/618972/

Version: Accepted Version

Publisher: Taylor \& Francis (Routledge)

DOI: https://doi.org/10.1080/14616688.2017.1357141

Please cite the published version 


\title{
The political economy of dive tourism: precarity at the periphery in Malaysia.
}

Mark P. Hampton (University of Kent), ${ }^{1}$ Julia Jeyacheya (Manchester Metropolitan University) $^{2}$ and Donna Lee (Manchester Metropolitan University) ${ }^{3}$

\section{Contact Author:}

Kent Business School and School of Anthropology and Conservation, University of Kent, Canterbury CT2 7PE.

Tel: 01227827264 (Direct); 01227827726 (General office)

Email: m.hampton@kent.ac.uk

2. Manchester Metropolitan University Business School, All Saints Campus, Oxford Road, Manchester, M15 6BH. Tel: 01612471362

Email: j.jeyacheya@mmu.ac.uk

3. Manchester Metropolitan University Business School, All Saints Campus, Oxford Road, Manchester, M15 6BH. Tel: 01612473976

Email: d.lee@mmu.ac.uk

\begin{abstract}
Using a critical political economy approach and the concept of labour precarity, the international dive tourism industry in Sabah, Malaysia and its workers' vulnerabilities are interrogated. Fieldwork data highlights dive tourism's socio-economic impacts and the precarity of labour within the international tourism sector and also critiques it as a development strategy for a peripheral region. The paper challenges the optimistic views of labour precarity found in the existing political economy literature. Rather than identifying labour empowerment, evidence demonstrates significant worker vulnerability, uncertainty, and contingency - especially among ethnic minorities - resulting from Malaysia's state-led rentier economy.
\end{abstract}


Keywords: precarity; rentier state; labour; communities; Malaysia; Borneo.

\section{Introduction}

South-East Asia has seen booming international tourism, specifically to its coasts and islands. The region hosted over 104.6 million international arrivals in 2015 with an expenditure of over $\$ 108.2$ billion with a growth rate in international arrivals of over $7.6 \%$ over $2014-15$ (UNWTO, 2016). This article focuses on one rapidly growing - and increasingly significant sector - scuba dive tourism. We focus on the Malaysian state of Sabah to explore the political economy of this growing niche sector. Our case study utilises a critical political economy approach, operationalising the concepts of rentier state and labour precarity in the context of work and workers in the tourism industry. We analyse field data that highlights certain ethnic, political and socio-economic impacts of the development of tourism generally, and dive tourism specifically. Our objective is to offer new conceptually driven, empirically rich insights into the ethnic inequities and overall labour precarity of the international tourism industry as a lead development strategy for Sabah. The analysis also informs broader scholarly and policy debates around the emergence of tourism as a development tool, especially in small island developing states (SIDS).

The rentier state concept - most commonly applied to economic development in oilrich states - describes the political economy of states where a particular minority are involved in wealth production and where substantial income is generated not from domestic production but from externally generated revenues (such as international tourism or, as in most rentier states, oil). This occurs where domestic production is insufficient to support economic growth. Rentier states often feature embedded state patronage to assist particular groups and repress opposition groups in order to retain political power, commonly leading to authoritarian regimes (Gomez and Jomo, 1999). This article explores Malaysia's political economy which displays many rentier features including a reliance on natural resource exports (and increasing investment in the international tourism sector to drive economic growth) as well as a patronage system of authoritarian rule by a particular ethnic elite. In the context of these marked political features, economic development is precarious and labour in the tourism industry typically experiences vulnerability, uncertainty and contingency.

The concept of precarity is increasingly commonplace in the social sciences and recent scholarship in the sub-disciplines of Political Economy and International Political Economy (IPE) has begun to employ the concept of precarity to explore the impact on labour of the fast growing service sector in developed economies. Rather optimistically, this 
literature suggests that service industry growth creates opportunities for the empowerment of labour. This case study of Sabah's tourism industry, as well as recent research into tourism in the Seychelles (Lee et al., 2015) challenges this optimistic view. Rather than identifying workers' empowerment, we find evidence of labour precarity in Sabah, especially among certain ethnic groups, as a result of the restructuring of the Malaysian economy towards a rentier state which began in the 1970s with the New Economic Policy and continued in the 1980s with increasing privatisation. These policies led not only to economic inequalities along ethnic lines, but also along class lines as capital interests were broadly privileged over those of labour.

This article has six sections. It starts with a brief review of the literature of the political economy of tourism in Less Developed Countries (LDCs) before examining precarity in relation to labour. Next, we introduce the background context and political economy of modern Malaysia and the state of Sabah. The study area of dive tourism around Sipadan island is then introduced before a brief highlight of the research methodology. We then present and analyse our findings and conclude with the conceptual and tourism policy implications of our research.

\section{The political economy and precarity of international tourism}

Development agencies and many LDC governments have seen tourism as an engine for economic growth since the 1960s resulting in significant state involvement and capitalintensive projects exemplified by large-scale resort development such as Nusa Dua in Bali, Indonesia or Cancun, Mexico (Lewis and Lewis, 2009; Torres and Momsen, 2005). International tourism's impacts have drawn academic interest in the political economy of LDC tourism since early work in the 1970s on the 'pleasure periphery' (Turner and Ash, 1975), de Kadt's book (1979) and pioneering work by Britton (1982) applying dependency theory to enclaves. For brevity, we will not review the literature of the political economy of LDC tourism since that has been thoroughly covered by Gibson (2009). Since Gibson's review, however, emerging themes have developed in the literature and include Ferguson's (2010) work linking local impacts to IPE; Duffy (2015) on the IPE of nature tourism; d'Hautessere (2015) on tourism's unequal relations in the French Pacific; Hampton and Jeyacheya (2015) on power relations and island tourism in Indonesia; Sinclair-Maragh and Dursoy (2015) who revisit theories of imperialism as applied to Jamaican residents' perception of foreign direct investment (FDI) in tourism, and Hill (2017) on the political economy of land grabs in marine parks in Malaysia, so called "blue grabbing". 
This emergent literature can be developed further by utilising the concept of labour precarity to critically analyse the political economy of international tourism. Labour can, and typically in LDCs does, find itself in a precarious position in many ways depending on different structural and agential factors including the industry's structure, labour's bargaining power within the state and industry, working conditions, the casual nature of the work, or whether the work is legitimated or not. As has been noted elsewhere, precarity exists across a wide spectrum of labour including the more obvious unskilled, female, and migrant workers to the less obvious highly educated workers in the creative industries (Lee et al., 2015). The concept of precarity has recently emerged in post-structuralist and Marxist literature to analyse the condition of labour in late modern capitalism (Hardt and Negri, 2000), a condition which, it is argued, offers service sector workers, in particular, opportunities to overcome exploitation. According to Robinson (2011) precarity can provide labour with more flexible ways of working as happens with the increasing regularisation of casual contract labour found in late modern capitalist economies. Workers in this situation are often highly networked (using professional social media) and tend to work collaboratively within/between these networks. These working practices, it is argued, generate new social relationships within labour in service sectors particularly among people who would otherwise be isolated economically, politically and socially (Lee et al., 2015, p.197). These novel networked social structures in turn provide opportunities to create new forms of social and political movements. As such this literature suggests that precarious work in late modern capitalism is a vehicle for a new progressive politics, or even in its most progressive guise, a new form of communism (Hardt and Negri, 2000) ${ }^{1}$.

Unsurprisingly, this optimistic view of the impact of precarious work has faced scholarly challenges. Not only is there little evidence of this new form of progressive politics (and no evidence of a re-emergence of communist movements), arguments ignore continuing differences between workers: differences which mean that workers experience flexible and casual contracts in different ways due to precarity resulting from other factors including gender, class, ethnicity and nationality (Thompson, 2005; Federici, 2010). The precarious condition of labour in the tourism industry - where work is often seasonal, low paid, and dominated by migrants with little/no political power - is unlikely to lead to workers' social and political empowerment that Hardt and Negri and others suggest is a feature of service sector labour (Lee et al., 2005, p.197).

In order to interrogate the condition of labour in tourism (arguably the fastest growing service industry) we present a case study of Sabah's dive tourism industry. Our study finds 
little evidence of the positive social and political consequences envisaged by the dominant scholarly analysis of the impact of service sector growth on labour. Instead, our data highlights the more varied and generally negative experience that precarity creates for workers in the Malaysian tourism industry and that, in this instance, ethnic differences differences ignored or glossed over in existing precarity research - is a key factor, not only in creating the condition of work precarity, but also in determining fragmented experiences of work precarity in this industry. Our analysis contributes to conceptual debates by providing a necessary corrective to what appears to be an overly optimistic view of the impact of deepening precarity resulting from difference in Sabah's fast-growing tourism sector.

\section{Rentier political economy of Malaysia and Sabah}

Malaysia has an ethnically determined and federated polity driven by its physical geography, recent colonial history and ethnic mix. The country consists of West (peninsula) Malaysia and East Malaysia (Malaysian Borneo) comprising two large states, Sabah and Sarawak, and the Labuan federal territory. Kahin (1992) comments that West Malaysia can be seen as the political/economic "core", whereas the two Borneo states comprise the "periphery". The population of around 29.9 million, the majority of whom live in peninsula Malaysia, has an interesting racial mix consisting of roughly 50\% Malays (Bumiputras), 25\% MalaysianChinese and around 10\% Malaysian-Indian. The remainder comprises indigenous peoples especially in Sabah and Sarawak including the Kadazan-Dusun, Dayak and Bajau (Department of Statistics Malaysia, 2014).

The political landscape of post-independence Malaysia has been dominated by an authoritarian alliance government. The UMNO (United Malays National Organisation) has been in power nationally since 1957 as well as ruling the majority of the state governments. Since the 1970s, the UMNO has arguably dominated the Barisan Nasional (BN) right wing alliance. Although significant left-wing and pro-democracy movements such as Bersih, or the opposition party Pakatan Rakyat (People's Alliance) have challenged UMNO, the governing $\mathrm{BN}$ alliance has maintained its dominance through authoritarian measures. Opposition leaders, including the former opposition leader Anwar Ibrahim, have been traduced and imprisoned (Adam and Koswanage, 2016; Latiff, 2016; Ramzy, 2015), whilst most opposition alliances have collapsed in the face of state-sanctioned repression such as the Sedition Act and Internal Security Act - combined with the difficulties of maintaining unity among a heady mix of Islamists and secular parties. 
In this context, the UMNO developed what Gomez and Jomo (1999) describe as a rentier approach to economic development where the tight nexus between the political and corporate elites drives economic policy (Khan and Jomo, 2000) thereby achieving improvements in poverty indicators but at the cost of increasing intra-ethnic economic inequalities. The public-private nexus at the heart of the Malaysian political economy leads to rent-seeking by privileged Malay elites. This rent-seeking approach arguably began in the 1970s when the governing UMNO introduced the New Economic Policy (NEP), a stateinterventionist approach to industrial and economic development that explicitly privileged Malays over the Chinese-Malaysians and Indian-Malaysians. This national level social engineering attempted to target economic inequalities, namely the predominantly rural Malay population who were perceived as being economically disadvantaged relative to Malaysia's other races.

In 1969 Malays owned 1.5\% of business compared to Malaysian-Chinese ownership of almost 23\%. Such inequities resulted in social unrest and race riots (Ritchie, 2004) and the cultivation of Malay businesses - unsurprisingly - concentrated Malay political and corporate power in government and state organisations. Several socio-economic barriers to Chinese and Malaysian-Indian mainstreaming followed including preferential loans and grants for Bumiputras for business start-ups, which led to non-Bumiputra being marginalised both professionally and economically (Ritchie, 2004). The Economist (2013b) bluntly described the NEP as being 'central to a system of corrupt patronage' but as Ritchie noted, as long as these discriminatory policies generated rapid economic growth, there was little opposition to the rentier state.

The NEP's controversial effects and the UMNO's continuing political dominance in the governing BN alliance governments, meant that the NEP encouraged Malaysian-Chinese entrepreneurs to create alliances with Malay politicians and bureaucrats. White (2004, p.415) argues that "political manoeuvring should be viewed as a key entrepreneurial skill ... While state patronage played a large part in corporate success, Malaysian business leaders still had to be competent entrepreneurs to reap the benefits from those government concessions and favours'. He locates this within the wider context of "crony capitalism" which he contends is commonplace across South-East Asia. This mix of crony capitalism, and its interaction with ethnicity and privileging Malays over other ethnic groups, forms the specific, highly complex cultural, political and economic context within which we analyse tourism in Malaysia and the precarity of the industry. 
The 1981 election of Prime Minister Mahathir Mohamad saw a shift towards partial privatisation and deregulation: or the "dual economy" (Ritchie, 2004). This led to rapid economic growth but was underwritten by continuing rent allocation to Malay corporate interests as well as requiring extensive foreign direct investment (FDI) by global companies including Carlsberg and Nestle who went on to dominate the manufacturing sector by taking advantage of the low cost labour market. The "dual economy" approach further concentrated wealth in the Malay elite.

The pronounced economic and political inequalities have not hampered Malaysia's significant economic development since the 1980s (Crouch, 1996) as demonstrated by continuous high growth rates, even in times of global economic turbulence, averaging $5.7 \%$ per year since 2010 (World Bank, 2016). While broadly continuing to grow, the Malaysian economy is currently in something of a crisis, with high government debt, corruption allegations at the very highest level (Nambiar, 2016) slowing growth rates and poor prospects for recovery given declining world commodity prices (Malaysia is heavily dependent upon oil, natural gas and palm oil exports) and the depreciating Ringgit.

Malaysia's pattern of economic growth has benefited capital at the expense of labour, and repressive labour policies mean that the Malaysian workforce remains low paid and lowskilled (Jomo and Todd, 1994; Ritchie, 2004). More recently it has been argued that Malaysia is starting to lose its competitive advantage of low labour cost to emerging ASEAN economies such as Vietnam and Cambodia and is beginning to experience the "middle income trap". ${ }^{2}$ A low-skilled workforce makes economic diversification difficult, political problems notwithstanding, and partially explains the attraction of developing international tourism to drive economic growth, as well as a short-term tactic to attract FDI.

The political economy of the ethnic mix and local politics seen in West Malaysia can also be observed in Sabah which has a population of 3.4 million (Department of Statistics Malaysia, 2014) and is located close to the southern Philippines and Indonesia. Sabah has significant ethnic groups such as the Bajau Laut (sea Bajau) who have resided in the region for centuries and whose presence predates modern nation states. (Brunt, 2013; Clifton et al., 2014). The Bajau face an ongoing issue of statelessness, which we return to below. This culminates in porous international borders and, as a result, sizeable flows of refugees and other migrants; by the mid-2000s Sabah had an estimated one million overseas residents (Sadiq, 2008).

Sabah, especially the eastern coastal town of Semporna and its offshore islands, has seen significant population inflows especially from the Philippines since the 1970s. The civil 
war in the southern Philippines (the Mindanao insurgency of 1970-77) resulted in the largest exodus of refugees fleeing conflict and seeking refuge in Sabah. The UNHCR (UN High Commissioner for Refugees) and the Malaysian government cooperated to ensure that "thousands" of Bajau Laut as well as other Filipino groups were given refugee status and a special refugee document, the IMM13 (Brunt, 2013). Estimates of numbers are politicised and highly contested, but UNHCR estimated around 100,000 arrivals in this period (Sadiq, 2008). Moreover, if the IMM13 certificate was not renewed, holders would fall into "irregular" immigration status. However, once the peace treaty was signed in the Philippines, after 1978 IMM13 holders were no longer officially recognised as "refugees", yet this was the largest phase of immigration and, according to Sadiq, (2008, p.106) local people in Sabah increasingly perceived these incomers to be economic migrants. However, the question over immigrant status is somewhat opaque and it appears that citizenship rights were based on paperwork rather than civil, social or political rights, in other words, they had 'documentary citizenship' or became in effect 'paper citizens' (Sadiq, 2008). After 2001 the Malaysian immigration authorities revoked the IMM13 "refugee" status and people's right to remain in Malaysia became conditional upon obtaining a work permit (Brunt, 2013).

Another important aspect of Sabah's political economy concerns land ownership and tenure. Mirroring patterns of cronyism and rentier politics seen at the state level, Sabah also experiences "internal land grabs" where the state and the elite private business community collaborate to ensure the "concentration of access to public and community land in the hands of a favoured set of domestic corporate actors and their patrons in the political-bureaucratic elite' (Cramb, 2013). This has significant implications for Sabah's local communities affected by international tourism: a key issue we discuss below.

This brief overview of Malaysia's political economy illustrates the context within which we can analyse international tourism's effects on Sabah's local communities. In common with the majority of LDCs, tourism for economic development has been a key part of Malaysian national planning for many years with the Ministry of Arts, Culture and Tourism created in 1987 to lead the industry's expansion. Tourism as a development tool was noted in several national Five Year Plans, and became prominent in the Sixth Malaysia Plan (1991-5). In 2004 the Ministry of Tourism was reorganised to focus entirely on international tourism. This was to ensure that, institutionally, the Malaysian state could restructure the economy so that tourism quickly became the second largest sector after manufacturing. By 2015 Malaysia had 25.7 million international arrivals generating around US $\$ 17.5$ billion in receipts. Tourism directly contributed around $4.4 \%$ of GDP and accounted for 1.6 million 
jobs both directly and indirectly, around $11.4 \%$ of total employment (UNWTO, 2016; WTTC, 2016).

But rather than develop conventional tourism such as beach resorts - where it would face fierce regional and global competition - the Malaysian state has focussed strategically on developing niche tourism. The most recent development plan, the Eleventh Malaysia Plan (2016-20) promotes "nature and adventure" tourism to exploit the country's asserted "world class" ecotourism potential, especially rainforest and coral reefs. Dive tourism in particular is seen by the (now renamed) Ministry of Tourism and Culture, as a rapidly-growing, highyielding international tourism sector. The global demand for scuba diving and associated dive tourism continues to boom with estimates from the largest certifying agency, PADI (2016) of 3-6 million divers globally. PADI alone certifies an average of 900,000 divers per year.

Sabah is promoted as Malaysia's "premier ecotourism destination" by the federal Ministry of Tourism and Culture. At state level, Sabah's tourism is organised under the aegis of the Ministry of Tourism, Culture and Environment with a strategic planning remit, and it oversees the Sabah Tourism Board (responsible for marketing) and Sabah Parks (who manage the national parks and protected areas). In 2015 Sabah had 3.17 million tourist arrivals, of whom 978,000 were international visitors (Sabah Tourism, 2016) and of those, Sabah hosts around 63,000 divers annually to Sipadan and nearby islands (Malaysian Association of Tour and Travel Agents cited in The Star, 2014).

Overall, the restructuring of the Malaysian economy to develop niche tourism appears to be successful for capital because it has generated high levels of income from the large numbers of higher-income overseas visitors. However, the sustainability of the strategy is problematic given the negative impact of the development of international dive tourism on labour. We examine these impacts in the next section.

\section{Dive tourism at Sipadan and Mabul islands}

Sipadan is arguably the most iconic, best-known Malaysian dive site. It is located around 40 kilometres off Sabah's east coast and accessed via boat from the nearest port (Semporna) or nearby islands. Air access is via Tawau domestic airport, inland from Semporna, and flights connect with Kota Kinabalu international airport and elsewhere in Malaysia.

Sipadan is often listed in the top ten world dive destinations and is seen as an aspirational dive site (Lew, 2013, Musa, 2002). It is an oceanic coral island with a huge 600 metre drop off and is famous for large pelagic fish, sharks, turtles and schooling barracuda. It is a global biodiversity "hotspot" hosting a large number of different marine species. 
However, unlike other Malaysian islands, divers' accommodation is not on Sipadan itself but on Mabul island, located 20 minutes boat ride away. This was due to the dive operators being relocated from Sipadan by the government in 2004: 'To protect Sipadan's biodiversity, Mabul became a "sacrifice area" (Hamzah and Lew, 2013). Diving at Sipadan is limited with a daily quota of only 120 dive permits issued by Sabah Parks. Divers are mostly highly experienced and stay in resorts on Mabul: typically "water village" luxury developments on stilts over the shallows. In 2014 there were nine dive operators on Mabul. In addition, there is some backpacker accommodation, with small businesses and village homestays.

Mabul has an estimated population of 2,500 with a mix of Bajau Laut, and former Filipino refugees (Hamzah et al., 2012). Unlike other dive destinations in peninsula Malaysia such as the Perhentian islands (Hamzah and Hampton, 2013) Sabah's east coast islands can be dived all year round so there are not distinct "closed" or tourist seasons.

\section{[FIGURE 1]}

The physical layout of Mabul is most striking (Figure 1) making it an obvious choice for the strategic development of dive tourism. The island is low-lying being only 1-2 metres above sea level and covering approximately 20 hectares. The villages (kampungs) are located mainly along the south-western shore. The narrow beach strip is occupied with high-density simple wooden huts or stilt houses. Walkways extend over the shallows and adjacent wooded areas are decreasing to accommodate more housing. A similar pattern emerges on the northeastern coast where another kampung is spreading towards the island's centre. The villages are differentiated by their ethnicity with the Suluk (broadly from the southern Philippines) settling on the south-western part of the island and the Bajau Laut settling on the northeastern coastal fringes in between dive resorts. Living standards among these communities are poor. Basic services such as electricity and waste disposal are unavailable in some areas and there have been cholera outbreaks. Interviews revealed concerns among tourism workers and business owners about the poverty and lack of sanitation especially in the Bajau Laut village although their response to these issues was mixed; some expressed empathy and wanted to help, while others considered it a threat to their business.

Mabul's second striking feature is the layout of the tourist areas which physically separates tourism, creating silos of (temporary imported) wealth divided from the poor communities. This is particularly pronounced in the location of the dive resorts in comparison with homestay accommodation: all but one resort are on the south-east coast while all 
homestays are found on the south-west coast. What have become, in effect, tourist zones are found in the three large areas across the major part of the island. Resorts are spacious with landscaped gardens, swimming pools and beachfronts. By comparison, the kampungs are restricted by the remaining forested areas, public spaces, fencing or increasing tourist infrastructure.

In the Sipadan-Mabul destination, the dive industry is structured with large, typically long-established Malaysian dive firms running luxury resorts. The employment pattern is a mixture of some expatriates but with an increasing number of local Malaysian dive professionals. This is quite unusual in South-East Asia, and the relatively high number of local dive masters (dive guides) and instructors is a result of a Sabah government scheme to train dive masters as part of a wider youth education programme (Daldeniz and Hampton, 2013). Although the majority of dive operators are sizeable with significant capital intensity, there are also some small businesses running accommodation in village homestays aimed at lower income markets (backpackers, domestic tourists). One dive operator has a clear market strategy targeting backpackers although with a different business model and tight cost controls (Table 1).

\section{[TABLE 1]}

\section{Methodology}

The key fieldwork site, Sipadan-Mabul, was selected because it is South-East Asia's leading dive destination. Fieldwork was part of a larger, two year funded international project on the socio-economic impacts of dive tourism in Malaysia. Fieldwork took place in July in the first year of the project, and then again in the following May. July was selected being peak season for tourism, and May as being shoulder season. ${ }^{3}$ The project was designed to allow a period of time in between fieldwork visits to process the first round of data collected and, crucially, for the opportunity for the researchers to reflect critically on the first visit and any lessons to be learnt. Fieldwork visits were relatively short employing rapid appraisal type techniques to collect as much useable data as possible in a fixed period limited by budget and time constraints. Whilst the challenges of using rapid appraisal are acknowledged - especially the risk of partial understandings from short periods of fieldwork (Newing, 2011a; McGee, 1997) - this was considered the most appropriate way to listen to "local voices" in the islands (Chambers, 1983; Ellis and Sheridan, 2014). 
The project team comprised four Malaysian and British academics (two from each country) and three Research Assistants (one British and two Germans). All of the Research Assistants (RAs) were familiar with tourism development research and were all formally qualified to Masters level (all were postgraduate research students). All the RAs had previous experience in qualitative research fieldwork in tourism and development, and two had worked with the academics on previous projects in Malaysia. In addition, the researchers organised further training on interviewing techniques for the RAs prior to fieldwork.

The composition of the team varied in the two rapid appraisal fieldwork visits. In the first year's fieldwork (July) the team comprised both of the Malaysian academics, one UK academic and an RA. ${ }^{4}$ In the second round (May) the team comprised one UK academic and the three RAs. The second round had some logistical problems and unfortunately just before the planned start, both Malaysian academics were unable to join the second trip. Fortunately, as it was a repeat visit and the islands had been visited only nine months previously, this was not insurmountable especially since reliable IT and mobile phone coverage had improved allowing regular communication, advice and input from the Malaysian colleagues.

Given the importance of reflexivity in the field (Cohen, 2013; Cupples and Kindon, 2014), team meetings took place each evening after the day's interviewing had finished. In addition, at the end of time in the field, a specific de-brief meeting was held to reflect on the fieldwork and share further impressions or final observations which were then recorded. These meetings allowed the team to explicitly reflect on the work in the field as "outsiders" who were utilising rapid appraisal techniques in the specific cultural context of these small islands as noted earlier in the paper.

Our approach was qualitative using semi-structured, in-depth interviews and participant observation. Average interview duration was around 45 minutes and $n=71$ interviews in total were held over the two visits with a range of stakeholders including instructors and dive masters, other dive shop staff (receptionists, clerical staff, boatmen, managers and owners), other tourism businesses, local residents and tourists. Concerning the selection of respondents, some key informants or "gatekeepers" were known to the team before arriving for fieldwork and were contacted in advance to set up initial interviews. This was then often combined with the "snowball"" technique to lead to further respondents in the islands. Thus the research utilised a mixture of convenience, purposive and some chain referral ("snowball") sampling.

Prior to fieldwork, a core list of interview questions was refined and agreed over several iterations between the lead researchers in Malaysia and the UK. This process of 
refining the interview protocols was designed to minimise the risk of poorly worded, ambiguous or "leading" questions and help reduce the risk of interviewer bias (Newing, 2011b). Concerning the "positionality" of our team for this project, three out of the four academics had extensive research experience in Malaysia, what Pagdin (1989) terms "preknowledge" of the context of tourism development, and two had undertaken prior research in the fieldwork location itself. That, combined with the explicit team discussions, reflection and also the time to consider the emerging findings over two rounds of fieldwork, reinforced Dupuis' notion of "self-reflection" (as discussed and amplified in Cohen, 2013, and also see Cupples and Kindon, 2014).

The informality of semi-structured interviews meant that respondents were able to talk more freely and raise their own issues than if the interviewer was forced to only use a more prescriptive pre-existing list of questions. Interview notes were recorded in field notebooks then written up as Word documents on laptop computers. Once returned from the field, interview transcripts were coded thematically using NVivo software to build "tree nodes" to analyse this qualitative data. "Theme documents" were then created for the research team which collated key topics and illustrated respondents' comments grouped by theme for further analysis. This analysis stage also saw robust discussions between the research team as the interview data was unpicked and examined in light of the theoretical angle (critical political economy) that we were pursuing.

\section{Analysis}

Our findings from the data collected are empirically and conceptually significant. Empirically our data demonstrates that labour in the dive tourism industry in this location is precarious. This is because it is structurally contingent and employment patterns in local communities both constitute, and are constituted by, existing ethnic cleavages, thus generating social and political precarity to add to the economic precarity of labour. Our findings therefore suggest that the predominant conceptualisation of work precarity in the service industries as an empowering socio-economic condition providing new opportunities for the emergence of progressive political movements is too optimistic. In what follows we provide evidence of an undercurrent of worker uncertainty, vulnerability and contingency in the dive tourism industry in the Sipadan-Mabul area. Evidence shows that census "regularisation exercises" (from 1970) and weak institutionalised citizenship programmes (since 1991) have physically and psychologically divided citizens according to their ethnicity, and thus social, economic and political status in society. 
Although the physical and spatial features of Mabul as noted earlier are characteristic of similar islands in the region, with emerging zoning patterns that segregate local people from tourists, it is the ethnic and cultural legacy of Sabah's recent past that differentiates it. This legacy contributes significantly to the precarious conditions experienced by some ethnic groups both as tourism employees and as island inhabitants. The growth of dive tourism businesses in many ways compounds the issues faced by some ethnicities. First, it demands a greatly differentiated workforce comprising a large workforce of unskilled, low wage workers and a small group of qualified, higher wage earners and business owners, creating highly diverse experiences of the tourism-led economic growth. Second, the dive tourism business relies on the same natural resources as local people for their livelihood creating precarity around resource capacity. Third, the balance of political influence and power not only favours dive resort owners, but also certain ethnicities and legal status (that is, not the stateless) following the general rentier- and patronage-based patterns of economic development characterising the Malaysian political economy.

One local official explained: 'almost all the development here [is] owned by Malaysian Chinese'. . . and available jobs were 'menial . . like housekeeping, cook, boatmen, and cleaner and gardener' and mainly taken by Filipino workers. For this particular ethnic group, however, economic opportunities and labour conditions on Mabul are considerably better than the Philippines, even though pay might be lower. One dive shop assistant from the Philippines explained how she was able to save enough each month from her wages to then support her older children:

... not so many jobs there [the Philippines]. The money is better here, we get food, accommodation. We send money back each month. I have kids. [Interviewer: How many?] Seven. Five are here, two stay there in the Philippines with the grandmother, before school in the Philippines, bring them here, the two boys go fishing, number three wants to take care of the smaller children.

These examples of tied employment were common among Filipino workers and others with non-Malaysian passports, whether they are legally allowed to work or not.

However, the Bajau Laut, who share similar menial jobs, are undocumented and many are either stateless, or "at risk of", statelessness. Apart from precarity arising from their condition (Clifton et al., 2014), their traditional migratory lifestyle is threatened as access to coasts and coral reefs are increasingly restricted for tourism or conservation. Although 
income from menial tourism jobs is significantly more than the traditional, subsistence-based economy, the capacity and mobility of the Bajau Laut to exercise a nomadic, sea-based existence is diminishing as tourism expands and "villages" or semi-permanent moorings are developed. Without land ownership or tenure, alternative opportunities for other economic activities are limited: a situation exacerbated as they lack political or economic power to resist attacks upon their livelihood. Furthermore, the Bajau Laut's condition and traditions means dive businesses are reluctant or unable to employ Bajau Laut in any capacity other than as casual labour. One resort manager said: 'Bajau are sea gypsies. They don't like being on the land but prefer to live sea life. They are born there and die there.'

This nuanced analysis of two groups reveals distinct experiences of precarity as tourism workers and inhabitants. On one hand, the Filipino workers are able to return "home" but choose to work in Mabul for better working conditions. Conversely, the Bajau Laut have no "other" home to return to and are less able to escape their precarious labour circumstances. What both groups share, however, is precarity over their access to work and remain in Malaysia. As noted earlier, this can only be legitimated through work permits or citizen ID cards issued by the government; but how this was done remained ambiguous in the eyes of many. Therefore, and over time, changes to documentation procedures and criteria have meant that permission can be granted (or removed) from some ethnicities and/or nationalities, leaving workers uncertain about their future. In one case, a local restaurant owner lost much of her workforce after documentation was denied to them during the last 'government operation'. She explained that the impact on her business was significant because her main customers, generating around $70 \%$ of her income, were local people and immigrants.

In common with much of Malaysian economic and political development, the Bumiputra - favoured politically and economically by successive BN government policies were less engaged in precarious work compared with other ethnicities. Few were employed in low-skilled, low paid work or as (highly skilled) dive instructors or dive masters, preferring to set up family businesses, such as homestays or souvenir shops. Conversely, the MalaysianChinese dominated the dive resort sector and larger businesses, despite national policies privileging some citizens over others. ${ }^{5}$ Of the small businesses on Mabul, recent unpublished research suggests that of the nine homestays, only one has a local business partner. The other eight are owned by either by Malaysian-Chinese/Malay investors from peninsular Malaysia or by the village head. ${ }^{6}$ 
The evidence so far shows that divisions of labour in dive tourism are strongly linked to the ethnic divisions of its workers and business owners. This has differentially located them within late modern capitalism, with some now being located on its periphery, and others at its core. As dive tourism has developed, the conditions of labour have become more precarious for all ethnicities. For the Bajau Laut, precarity appears fundamentally linked to their diminishing traditions and sea-based livelihood (compounded by their lack of legal status and statelessness), whilst the Filipinos' experience of precarity derives from conditions of labour in the neighbouring nation states of the Philippines and Malaysia. The nature of those precarities suggests that Filipinos were able to engage far more in the tourism industry than the Bajau Laut. Those at the core of late modern capitalism in the area, by contrast, have seemingly created many conditions of precarity by engaging in dive tourism. For those involved in dive tourism, the two main threats to their business and the workers was the threat to the environment (particularly coral reefs) that creates the demand for tourism in the first place, and more recently, the security situation.

Sipadan's status as a premier dive destination is critical for tourism in the region. Without this status it becomes just another dive site within a highly competitive sector. Indeed, according to one dive instructor, without dive tourism and 'the economic benefit of scuba diving, there is no reason to protect these areas. 'Yet despite this, most respondents felt that weak governance of the environment and natural resources and ad hoc policies were fundamental barriers to sustaining that benefit. This perpetuated multiple precarities within the tourism industry, and rather than empowering labour and business to address environmental issues that create uncertainty and contingency, the strategy to expand international tourism as the singular means of economic growth in the area, has had a disempowering effect.

The marine environment's health is crucial both for dive tourism and local communities and while enforcement to prevent destructive fishing practices (such as reef dynamiting) was evident, respondents suggested it was ineffective and, sometimes, nonexistent. Respondents from the diving community were especially vehement and critical of a) the marine parks management for disregarding their duties by taking 'their lunch from the fishing boats rather than fining them' (dive instructor), and b) ad hoc policies where 'the divers are regulated, [but] the fishermen aren't' (dive resort owner). The continued uncertainty over the future of the marine environment among dive operators and workers was considered a fundamental barrier to sustaining operations until the government have decide[d] what they want here: tourism or fishing industry' (dive resort owner). 
Power and influence in Mabul mirrors the rentier governance structures that characterise Malaysia. Political power resides with the owners of the large dive resorts (mainly Malaysian-Chinese), the principal investors in current/future tourism development projects (mainly Malaysian-Chinese but with increasing interest from firms in China itself) and government agencies responsible for immigration, environment and security. The impact of this on tourism workers and local communities is significant. To understand this more precisely we now examine the key precarities associated with the rentier political economy of the area and its impact on different ethnicities.

First, the rentier political economy creates conditions of overpopulation and overdevelopment. One dive resort's resident marine biologist observed: 'There are no guidelines for proper tourism development. There is no Master Plan, they [tourism developers] just refer to the District Officer.' Without such expert guidance, tourism workers and particularly small businesses, have limited powers to contribute to future development decisions. One local restaurant owner had strong views about the rate of development, but was reluctant to formally object: 'This is Malaysia. Our constitution says we are a democracy. But there is corruption. Certain investors have interests. And I need my licence renewed. Do you think they will renew my licence if they consider me a troublemaker?' Although this respondent was of Bumiputra origins, it is clear that wealth trumps ethnicity since the most influential group are the major investors. One owner of a smaller dive business expressed his worries in this way: 'Big companies, I don't know . . but to when, I show heart. Can't survive, I hear they kick out the small guys, just keep the big resorts. . . On Mabul the principal investors and large dive resort owners are predominantly MalaysianChinese. Thus, the political economy of dive tourism creates conditions of uncertainty and contingency for the Bumiputra whom, ironically, UMNO has sought to assist for decades.

Secondly, a common issue raised was the need for basic services and infrastructure for the kampungs because the main source of pollution from litter and sewage derives from these high-density poor communities. The main reason given by respondents to 'why the government has not addressed the lack of waste management and sewage treatment' was that the kampungs would eventually be replaced by dive resorts and local inhabitants transferred to another island. Evidently, this is speculation, but it is not improbable given that the majority of villagers are either former or existing irregular migrants or refugees. Similarly, the Bajau Laut whose presence pre-exists the Malaysian nation-state, and who, as stateless people, sit uncomfortably within bureaucratic categorisations, continue to be marginalised and impoverished by the rentier political economy. 
Ethnic tensions are a third key feature among dive tourism communities. Respondents from the largest dive resorts described Mabul's villagers using derogatory terms ('squatters', 'Philippine rebels', 'illegal immigrants') and blamed them for the lack of basic services and infrastructure to manage waste and sewage:

it [Mabul] has a severe problem with pollution, [but] before I give an answer, around $80-90 \%$ of them there are non-Malaysian, they are all squatters, because the land does not belong to them but [resort name here] owns this land, so it is a problem of pollution, especially human waste and plastic. (Manager, dive resort).

Fourthly, the growing security challenge threatening tourism adds to the precarity of the industry and tourism workers including increasing cross-border terrorism, kidnapping and armed crime associated with the southern Philippines. The armed incursion into eastern Sabah in 2013 that ended with a shootout and several deaths was global news (The Economist, 2013a). Tourist bookings for the next few months fell immediately and many countries issued travel advisories for Sabah's coast; although the industry recovered quickly. By July 2013 one of Sabah's largest dive operators declared 95\% occupancy (Hong, 2013). However, further incidents in 2014 - including kidnappings and murder of Chinese and Taiwanese tourists - led to more than 30,000 cancellations from Chinese tourists alone (Tourism Minister Nazir quoted in Sivanandam, 2014). In July 2014 armed gunmen attacked a Mabul dive resort and a Malaysian police officer was killed and another kidnapped, although no tourists were injured on that occasion and in May 2015, further kidnappings of Malaysian nationals occurred at Sabah's coast (Sario et al., 2015; The Telegraph, 2014).

The dive resorts' security is now a key concern. After the 2013 incursion the Malaysian government formed the Eastern Sabah Security Command combining armed forces, police and coastguard to boost maritime security. Ships patrol the tourist islands and nightly curfews are in place. Sabah has a long history of piracy, lawlessness and smuggling which, to some extent, is due to the area's geography given its long coastline and many islands between Semporna and the southern Philippines resulting in a highly porous border.

The impact of security concerns on Sabah's tourism is clear. International tourist arrivals fell from 1.1 million in 2013 to 978,000 in 2015 and Mabul's resorts had an estimated up to 50\% drop in business (Lew, 2014). At the time of writing (early 2107) the UK, US, Canada and Australia still have travel advisories remaining for Sabah's eastern coast and islands including Sipadan and Mabul. 
Given the strategic significance of international tourism to the area's economic development, plans appear to be in place to expand the industry. In 2014 news emerged of a Chinese company’s plans to develop a US\$0.75 billion Sipadan resort (Tam, 2014) but at the time of writing nothing further could be found about this project: perhaps reflecting investors' concerns about Sabah's ongoing security situation.

\section{Conclusion}

This article has provided data drawn from fieldwork on the impact of the dive tourism industry in Sabah, eastern Malaysia. It highlights the precarious position of labour in the dive tourism industry with issues of ethnicity embedded within a rentier political economy. We explored the ways in which workers from different ethnic groups experience work precarity in Mabul. We found that all ethnic groups, nationalities and legal documentation status experience labour precarity, but that some, such as the Bajau Laut, experience far higher levels than others.

The growth of the Malaysian economy is slowing; manufacturing is declining, and commodity prices are falling, especially oil exports which have arguably driven the country's economic growth since the Mahathir era. These recessionary trends highlight the continuing importance of international tourism for employment and FDI to the overall Malaysian economy. It is unsurprising, therefore, that the Malaysian government, like other developing countries, prioritises international tourism as a major economic development driver. Mabul has particular physical features that create opportunities for dive tourism as a niche product in a highly competitive market. The iconic and world-renown dive site of Sipadan and its surrounding area proved a useful case study to explore tourism's impact on LDCs' local communities in general with particular implications for SIDS.

The small island of Mabul hosts complex interactions between several different groups, nationalities and immigration status including Malaysian-Chinese, a few Malays, Bajau Laut and Filipinos who exist in an intersection between a form of late modern capitalism and a small island economy where fishing is the only other significant economic activity. We found evidence of a clear division of labour in dive tourism, a division closely linked to the ethnic divisions of its workers and business owners, demonstrating that the island's ethnic groups are differentially located within late modern capitalism. Ethnic variation both constitutes, and in turn is itself constituted by, a rentier political economy which privileges certain ethnic groups above others through cronyism and patronage. Following independence in 1957, the Malays became the economic and political elite under 
successive governments. In Mabul, and elsewhere in Malaysia, however, the growth of investment by Malaysian-Chinese in tourism resorts has somewhat undermined the Malay hegemony.

Irrespective of ethnic identities, our findings demonstrate the precarity of the dive tourism industry in general due to uncertainties around environmental degradation, and insecurities caused by terrorism and lawlessness. Ethnic differentiation, however, helps explain the more precarious experience of migrant Filipino labour as well as Bajau Laut in Mabul whose work is low paid, highly contingent, and insecure. Our evidence demonstrates that work precarity in Mabul's service sector has become a broadly negative experience, and highlights the key role played by different ethnicities which typically have been ignored or glossed over in the precarity literature thus far. Further, the paper argues that weak institutional citizenship in Malaysia has effectively divided citizens by ethnicity within this small island. This also links to the role of national policies such as the NEP that have significantly affected inhabitants' social relations. This is somewhat ironic as it appears to have empowered those it sought to discriminate against, whilst disempowering the nationally privileged ethnic groups (the Malays) that such policies were designed to assist. For the Bajau Laut, precarity appears fundamentally linked to their diminishing tradition of seabased livelihoods and underpinned by multiple issues stemming from their statelessness, whereas the Filipinos' lived experience of precarity is based upon the relative conditions of employment between the Philippines and Malaysia. In other words, the very nature of those precarities suggests that Filipinos were able to engage far more in the tourism industry than the Bajau Laut.

Overall, our research found that, unlike the somewhat optimistic view of work precarity commonly found in most of the current political economy literature, the international dive tourism industry in Mabul suggests that political empowerment was at best partial and limited in scope. Conversely, evidence emerged of worker vulnerability, ongoing uncertainty, and contingency, especially among certain ethnic minority groups which, we argue, originates fundamentally from the rentier political economy that has driven the Malaysian economy's restructuring since the 1970s. Regarding lessons beyond Malaysia for development policy and planning elsewhere, our findings suggest that work precarity overlies, and yet meshes with, existing patterns of ethnic groupings in the host community. This has policy implications for governments wishing to harness international tourism to drive more inclusive economic growth in coastal and other communities (Lee et al., 2015). Further comparative research in other LDCs could illustrate the policy levers that might 
reduce labour precarity and allow more effective empowerment of host communities enabling them to gain economic and other benefits from hosting international tourism.

\section{Acknowledgements}

The research on which this paper reports is an output from the PMI2 Project funded by the UK Department of Business, Innovation and Skills (BIS) for the benefit of the Malaysian Higher Education Sector and the UK Higher Education Sector. Any views expressed are not necessarily those of BIS, nor British Council. In addition we thank Bilge Daldeniz, Jorn Fricke and Caroline Walsh for their assistance with fieldwork, as well as the interview respondents who generously gave up their time. We also thank Sheela Agarwal, Helen Brunt, Julian Clifton, Amran Hamzah and Catherine Robinson for their helpful comments on earlier versions of the paper, and Jorn Fricke for preparing the map. The usual disclaimers apply. 


\section{References.}

Adam, S. and Koswanage, L. (2016) Malaysia Opposition Leader Detained by Anti-Graft Commission. Bloomberg. 29 June. https://www.bloomberg.com/news/articles/2016-0629/malaysia-opposition-leader-detained-by-anti-graft-commission

Britton, S. (1982) The Political Economy of Tourism in the Third World. Annals of Tourism Research, 9: 331-358.

Brunt, H. (2013) Stateless Stakeholders: Seen But Not Heard?' The Case of the Sama Dilaut in Sabah, Malaysia. MA thesis, University of Sussex.

Chambers, R. (1983) Rural Development. Putting the Last First. London: Longman

Clifton, J., Acciaioli, G., Brunt, H., Dressler, W., Fabinyi, M. and Singh, S. (2014)

Statelessness and conservation: exploring the implications of a neo-liberal governance agenda. Tilburg Law Review 19: 80-88.

Cohen, S. A. (2013). Reflections on reflexivity in leisure and tourism studies. Leisure Studies, 32(3): 333-337.

Cupples, J. and Kindon, S. (2014) Returning to University and Writing the Field. In Scheyvens, R. (ed) Development Fieldwork: A Practical Guide. (Second Edition) Sage: London.

Cramb, R. (2013) A Malaysian Land grab? The Political Economy of Large-Scale Oil Palm Development in Sarawak. LDPI Working Paper 50. The Hague:

International Institute of Social Studies.

Crouch, H. (1996) Government and Society in Malaysia. Ithaca: Cornell University Press.

Daldeniz, B. and Hampton, M.P (2013) Dive tourism and local communities: active participation or passive impacts? Case studies from Malaysia. International Journal of Tourism Research. 15 (5): 507-520.

Department of Statistics Malaysia (2014) Population and Demography. http://www.statistics.gov.my/portal/index.php?option=com content\&view $=$ article \&id=1465

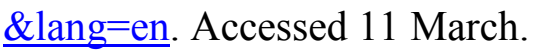

d'Hauteserre, A. (2015) Tourism in the French Pacific. In Tourism in Pacific Islands: Current Issues and Future Challenges edited by Pratt, S. and Harrison, D. pp 22-35. London: Routledge.

de Kadt, E. (ed) (1979) Tourism - Passport to Development? Oxford University Press, Oxford. 
Dimmock, K. (2004) Managing recreational scuba experiences: exploring business challenges for New South Wales dive tourism managers. Tourism Review International, 7 (2): $67-80$.

Duffy, R. (2015) Nature-Based Tourism and Neoliberalism: Concealing Contradictions. Tourism Geographies, 17 (4): 529-543.

The Economist (2013a) Malaysia invaded: The sultan's Sabah swing. 23 February. http://www.economist.com/news/asia/21572251-chaotic-south-philippines-muslims-launchforeign-policy-sultans-sabah-swing

The Economist (2013b) Malaysia: A Never Ending Policy. 27 April.

http://www.economist.com/news/briefing/21576654-elections-may-could-mark-turningpoint-never-ending-policy

Ellis, S. and Sheridan, L. (2014) A Critical Reflection on the Role of Stakeholders in Sustainable Tourism Development in Least-Developed Countries. Tourism Planning and Development, 11 (4): 467-471.

Federici, S (2008) Precarious Labour: A Feminist Viewpoint. In the Middle of the Whirlwind, https://inthemiddleofthewhirlwind.wordpress.com/precarious-labor-a-feminist-viewpoint Ferguson, L. (2010) Tourism development and the restructuring of social reproduction in Central America. Review of International Political Economy, 17 (5): 860-888.

Gibson, C. (2009) Geographies of tourism: critical research on capitalism and local livelihoods. Progress in Human Geography 33 (4): 527-534.

Gomez, E.T. and Jomo K. S. (Second Edition) (1999) Malaysia's Political Economy: Politics, Patronage and Profits. Cambridge: Cambridge University Press.

Hampton, M.P. and Jeyacheya, J. (2015) Power, Ownership and Tourism in Small Islands: evidence from Indonesia. World Development. 70: 481-495.

Hamzah, A. and Hampton, M.P. (2013) Resilience and Non-Linear Change in Island Tourism. Tourism Geographies, 15 (1): 43-67.

Hamzah, A., Hilmi, N., and Alias, L.J.(2012) Report for Preliminary Socio-Cultural Survey at Pulau Mabul. Long Term Research Scheme Vote 4L801. Kuala Lumpur: Ministry of Higher Education.

Hamzah, A. and Lew, A. (2013) Review 4: Mabul Island. The social and environmental impacts of a dive tourism sacrifice area. In Scuba Diving Tourism edited by Musa, G. and Dimmock, K. pp190-193. London: Routledge.

Hardt, M. and Negri, A. (2000) Empire. Cambridge, MA: Harvard University Press. 
Hill, A. (2017) Blue grabbing: Reviewing marine conservation in Redang Island Marine Park, Malaysia. Geoforum, 79: 97-100.

Hong, C. (2013) The resurgence of Sabah's tourist industry. Business Circle. 27 August. http://www.businesscircle.com.my/the-resurgence-of-sabahs-tourism-industry/.

Johannesson, G.T. (2005) Tourist translation: Actor-network theory and tourism research. Tourist Studies, 5(2): 133-150.

Jomo, K.S and Todd, P. (1994) Trade Unions and the state in Peninsular Malaysia. Oxford: Oxford University Press.

Kahin, A., (1992) Crisis on the Periphery: The Rift Between Kuala Lumpur and Sabah. Pacific Affairs, 65 (1): 30-49.

Khan, M. H and Jomo, K.S (2000) Rents, Rent-Seeking and Economic Development: Theory and the Asian Evidence. Cambridge: Cambridge University Press.

Latour, B. (2005) Reassembling the social: An introduction to actor-network theory. Oxford: Oxford University Press.

Latiff, R. (2016) Malaysia arrests pro-democracy leader ahead of rally calling for Najib Razak to resign. Sydney Morning Herald. Online. 19 November.

http://www.smh.com.au/world/malaysia-arrests-prodemocracy-leader-ahead-of-rally-callingfor-najib-razak-to-resign-20161118-gssx 7s.html

Lazzarato, M. (2006) Immaterial Labour. In Radical Thought in Italy: A Potential Politics. Edited by P. Virno and M Hardt. pp133-50. Minneapolis: Minnesota University Press. Lee, D., Hampton, M., and Jeyacheya, J. (2015) The political economy of precarious work in the tourist industry in Small Island Developing States. Review of International Political Economy, 22 (1): 194-223.

Lew, A. (2013) Where to Dive? Ranking the World's top Scuba Diving Locations. Read at 6th Tourism Outlook Conference, 2nd Coastal, Island \& Tropical Tourism Conference. Kota Kinabalu, Malaysia. 22-24 April.

Lew, A. (2014) Resilience in Community Based Tourism: Batu Puteh and Pulau Mabul in Sabah, Malaysia. Tourism Communities:

http://www.tourismcommunities.com/uploads/2/8/8/4/28845077/resilinece in_sabaha lew.pdf

Lewis, J. and Lewis, B.(2009) Bali's Silent Crisis. Lanham, MD: Lexington Books. Li, Y., Kun, L and Feng, X. (2007) The problem of 'Guanxi' for actualizing community tourism: A case study of relationship networking in China. Tourism Geographies, 9 (2): 115138. 
McGee, R. (1997) Ethnography and Rapid Appraisal in Doctoral Research. In

Methodological Complementarity. PLA Notes: Notes on Participatory Learning and Action, Number 28. February. London: Institute for Environment and International Development. pp.55-58.

Michael, M. (2017) Actor-Network theory. Trials, trails and translation. London: Sage.

Moore, P. (2012) Where is the study of work in critical IPE? International Politics, 49 (2): $215-37$

Musa, G. (2002) Sipadan: a SCUBA Diving Paradise: an Analysis of Tourism Impact, Divers Satisfaction and Tourism Management. Tourism Geographies, 4(2): 195-209.

Nambiar, S. (2016) Can Malaysia revive its economy in 2016? East Asia Forum, 9 January, http://www.eastasiaforum.org/2016/01/09/can-malaysia-revive-its-economy-in-2016/

Newing, H. (2011a) Introduction: Social Sciences Research in Conservation. In Newing, H., Eagle, C., Puri, R. and Watson, C. Conducting Research in Conservation. A Social Science Perspective. Routledge: London. pp.3-21

Newing, H. (2011b) Qualitative interviews and focus groups. In Newing, H., Eagle, C., Puri, R. and Watson, C. Conducting Research in Conservation. A Social Science Perspective. Routledge: London. pp.98-118 PADI, (2016) Worldwide Corporate Statistics 2016. Professional Association of Diver Instructors, https://www.padi.com/sites/default/files/documents/aboutpadi/statistics/PADI_2016_WW_Statistics.pdf

Pagdin, C., (1989) Assessing Tourism Impacts in the Third World: a Nepal Case Study. Progress in Planning, 44 (3): 185-226.

Ramzy, A. (2015) Daughter of Jailed Malaysian Opposition Leader Is Arrested. New York Times. Online. March 16. https://www.nytimes.com/2015/03/17/world/asia/daughter-ofjailed-malaysian-opposition-leader-is-arrested.html? $\mathrm{r}=0$

Ritchie, B.K (2004) Politics and Economic Reform in Malaysia. William Davidson Institute Working Paper 655. Ann Arbor: University of Michigan.

Robinson, A (2011) In Theory Precarians of All Countries, Unite! Ceasefire, March 18. http://ceasefiremagazine.co.uk/in-theory-precarity

Sabah Tourism, (2016) Sabah: Visitors Arrival by Nationality 2015. Tourism Statistics. http://www.sabahtourism.com/sites/default/files/visitor-2015.pdf

Sadiq, K. (2005) When States Prefer Non-Citizens Over Citizens: Conflict Over Illegal Immigration into Malaysia. International Studies Quarterly, 49: 101-122. 
Sadiq, K. (2008) Paper Citizens: How illegal immigrants acquire citizenship in developing countries. New York: Oxford University Press.

Sario, R, Lee, S. and Nikanis, M. (2015) Gunmen kidnap restaurant manager and customer in Sabah. The Star. 15 May. http://www.thestar.com.my/News/Nation/2015/05/15/Gunmenkidnap-restaurant-manager-and-customer-in-Sabah/

Sinclair-Maragh, G. and Gursoy, D. (2015) Imperialism and tourism: The case of developing island countries. Annals of Tourism Research, 50: 143-158.

Sivanandam, H. (2014) Nazri: Sabah kidnappings affecting tourism industry more than MH370. The Star. 17 June.

http://www.thestar.com.my/News/Nation/2014/06/17/Sabah-kidnappings-affecting-tourismmore-than-MH370/

Standing, G. (2011) The Precariat: The New Dangerous Class. London: Bloomsbury Academic.

The Star (2014) Attack another dent on tourism in Sabah, says MATTA. 16 July. http://www.thestar.com.my/News/Nation/2014/07/16/Attack-another-dent-on-tourism-in$\underline{\text { Sabah-says-MATTA/ }}$

Tam, S. (2014) Outrage over Sipadan development. Yahoo News Malaysia. 13 January. http://my.news.yahoo.com/outrage-over-sipadan-development-104032728.html

The Telegraph (2014) Gunmen attack diving resort on Malaysia's Borneo island. 13 July. http://www.telegraph.co.uk/news/worldnews/asia/malaysia/10964604/Gunmen-attack-divingresort-on-Malaysias-Borneo-island.html

Thompson, P. (2005) Foundation and Empire: A Critique of Hardt and Negri. Capital and Class, 86: 39-64.

Torres, R. and Momsen, J. (2005) Gingolandia: The Construction of a New Tourist Space in Mexico. Annals of the Association of American Geographers, 95(2): 314-335.

Turner, L. and Ash, J. (1975) The Golden Hordes. International Tourism and the Pleasure Periphery. Constable, London.

UNWTO (2016) Tourism Highlights. Madrid: UN World Tourism Organisation.

Vanar, M. (2014) China company looking at RM2.5bil tourism development project on Sipadan. 9 January, The Star http://www.thestar.com.my/Business/BusinessNews/2014/01/09/Followup-talks-with-China-company-on-Sipadan-project/ van der Duim, R.(2007) Tourismscapes: An Actor-Network perspective. Annals of Tourism Research, 34 (4): 961-976. 
van der Duim, R., Ren, C. and Joahnnesson, G.T. (2017) ANT: A decade of interfering with tourism. Annals of Tourism Research, 64: 139-149.

White, N.J. (2004) The Beginnings of Crony Capitalism: Business, Politics and Economic Development in Malaysia, c. 1955-70. Modern Asian Studies, 38 (2): 389-417.

World Bank, (2016) Malaysia overview. September.

http://www.worldbank.org/en/country/malaysia/overview

WTTC (2016) Economic Impact 2016 Malaysia. London: World Travel and Tourism Council. 


\section{Notes}

\footnotetext{
${ }^{1}$ It is useful, at this stage to acknowledge the growing literature from tourism and other disciplines on network theories, and its potential relevance to this paper. Space precludes this from our discussion however, we draw attention to the 2000s, a particularly prolific decade of writing about 'an alternative way of looking at and researching tourism' (van der Duim, Ren and Joahnnesson (2017, p.139). See Johannesson (2005), Latour (2005), Van der Duim (2007), and more recent publications by Michael (2017) and Van der Duim, Ren and Johannesson (2017).

${ }^{2}$ Personal communication, Professor Amran Hamzah, 5 October 2015

${ }^{3}$ Fieldwork took place in July 2008 and May 2009.

${ }^{4}$ Unfortunately, one of the UK academics was unable to join fieldwork either year due to personal circumstances.

${ }^{5}$ The success of this ethnic group could be attributed to guanxi, a Confucian idea which remains 'a major dynamic in Chinese society today' (Li, Lai and Feng, 2007: 116). A literal translation of guanxi, according to Li, Lai and Feng (2007) is 'personal relationship networking that permeates social and economic life', and thus highly influential.

${ }^{6}$ Personal communication, Professor Amran Hamzah, 5 October 2015.
} 
Table 1 Dive operators' Key Business Areas: Sipadan- Mabul.

\begin{tabular}{l|l}
\hline Generating Business Area & \\
\hline $\begin{array}{l}\text { Revenue type: } \\
\text { Dive package (all inclusive: } \\
\text { accommodation, food, diving) }\end{array}$ & $\begin{array}{l}\text { Main markets: } \\
\text { High end tourists (some } \\
\text { backpackers \& domestic } \\
\text { tourists) } \\
\text { High end tourists (some } \\
\text { backpackers \& domestic } \\
\text { tourists) } \\
\text { Backpackers (some domestic } \\
\text { tourists, few 'add-ons' for high } \\
\text { end tourists) } \\
\text { Backpackers (some domestic } \\
\text { tourists) }\end{array}$ \\
\hline
\end{tabular}

Source: fieldwork notes and adapted after Dimmock, 2004: 77. 
Figure 1. Map of Mabul island.

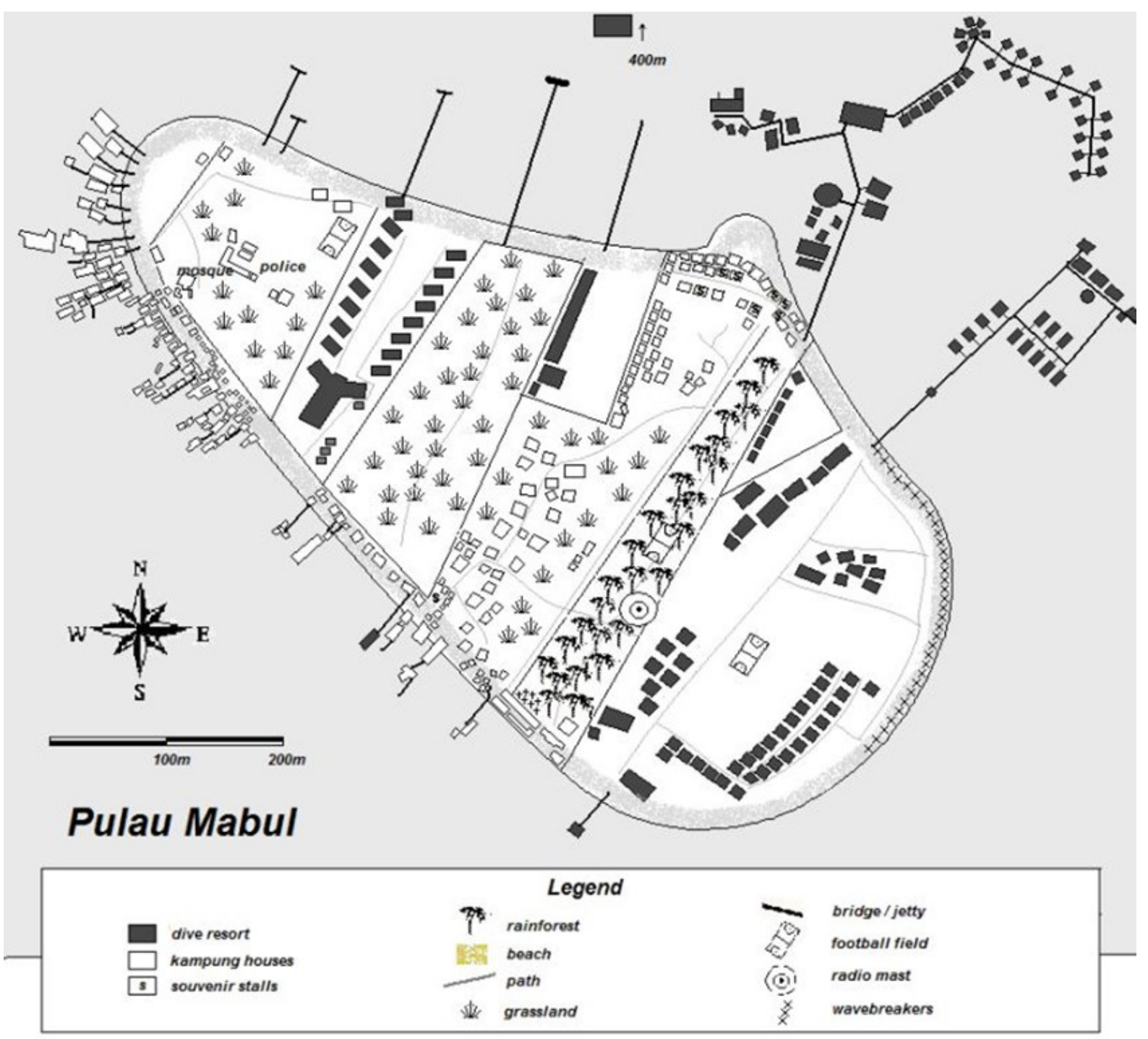

